\title{
The Impact of Sports Sponsorship on Brand Equity Dimensions: A Case of Castle Lager Brand in
}

\section{Zimbabwe}

\author{
Divaries Cosmas Jaravaza ${ }^{1}$, Alexander Guveya ${ }^{2}$ \\ Department of Marketing, Bindura University of Science Education, P.Bag 1020, Bindura, Zimbabwe
}

\begin{abstract}
Sports sponsorship involves huge sums of money whose return should be accounted for. The paper focuses on the Castle Lager soccer sponsorship (Castle Lager premier soccer league) in Zimbabweand strives to reveal its impact on three brand equity dimensions (brand awareness, brand loyalty and perceived quality). The three brand equity dimensions are based on Yoo and Donthue brand Equity model. Causal research design was used to determine the impact of sports sponsorship on brand equity dimensions. A sample of 200 respondents was selected from a total of 710000 soccer fans from Dynamos, Caps United, Highlanders and Harare City Football clubs. The data was collected in Harare (the capital city of Zimbabwe) only. A combination of judgmental and convenience sampling was used in stadia to identify soccer respondents. Structured questionnaires were used to gather data. Data was analyzed through correlation analysis using SPSS version 16.0.The obtained results indicates that Castle Lagersport sponsorship programs generate severalpositive outcomes on the three brand equity dimensions that are brand awareness ( $R$ square $=0.839)$, brand loyalty $(R$ square=0.668) and perceived quality $(R$ square $=0.573)$. Therefore, castle lager sports sponsorship could be seen as an effective marketing communication tool in order to achieve brand objectives. The authors recommend firms to invest in sponsorship programs so as to boost their brand equity.
\end{abstract}

Keywords: Brand equity, Sports sponsorship, Brand awareness, Brand loyalty, Perceived quality, Castle lager.

\section{Introduction}

In recent times the traditional marketing elements of communication, like advertising, public relations and sales promotion are now faced with challenges of reaching fragmented consumer markets and cutting through a clutter ofmessages aimed at consumers (Cornwell and Roy, 2003). Therefore, sport sponsorship as apromotional and marketing tool has become increasingly a more popular marketing communication vehicle in any industry.According to International Events Group (2012), the leading source of information in the sport sponsorship industry, defines sponsorship ascash or in-kind fee paid, particularly for sports, non-profit event or any organization in return for the access to the exploitable commercial potential associated with that property.In the past decades expenditures for sport sponsorship have grown at faster rates than expenditures on mass media advertising and sales promotion (Cornwell and Roy, 2013). The linkage of the brand with an event via sport sponsorship enables companies to reach both potential and existing consumers interest and attention thereby associating with the events that hold great importance to them. There is a possibility for sport sponsorship to bypass media clutter and provide an environment where a brand can reach the target customersand communicate to the right target audience and differentiate itself from othercompeting brands.

Nowadays companies seek return on investment by sponsoring soccer, but many of these companies do not know how to measure the effectiveness of their marketing activities or the impact of sport sponsorship on brand equity dimensions. Sports sponsorship allows the sponsors to communicate more directly and closely with their target market, but the effects of such marketing efforts on target markets and brand value are unidentified. It is important for the sponsor to measure sponsorship effectiveness. Enough research does not exist on measuring the effectiveness of sport sponsorship in Zimbabwe. In spite of the increasing importance of sponsorship as a marketing communication tool, little is known about how sport fans process this information in their brand assessment in Zimbabwe especially in the brewery industry.

\section{Conceptual and theoretical Literature}

Yoo and Donthu Multidimensional Brand Equity model Yoo and Donthu (2001), proposed the multidimensional brand equity model. The model was developed to bridge the gap between Ehrenberg and Aaker's models.Yoo and Donthu (2001), argue that the dimensions of brand equity in Ehrenberg and Aaker's brand equity models may not be an appropriate way of developing a multidimensional brand equity index because there are not equally distributed among three majordimensions of brand equity. Therefore the multidimensional brand equity model proposed to use brand awareness, brand loyalty and perceived quality as the three appropriate brand equity dimensions index. Cornwell and Roy (2003) argue that three dimensions may contribute differently to brand equity. The multidimensional brand equity model is equivalent to the higher order model (ten dimensional models) because the inter correctional paths of the multidimensional brand equity model can be converted to causal paths of the higher order model without adding new paths or deleting the existing ones (Pappu, Quester and Cooksey 2005). Yoo and Donthu (2001), argue that in higher order model the three dimensions are related to the higher order factor which can be referred to the higher order brand equity. Therefore the current research is based on this model proposed by Yoo and Donthu because brand awareness, brand loyalty and perceived quality are the three brand equity dimensions which can be converted to a higher 


\section{International Journal of Science and Research (IJSR) \\ ISSN (Online): 2319-7064}

Index Copernicus Value (2013): 6.14 | Impact Factor (2015): 6.391

model without adding or deleting the existing ones ( Yoo and Donthu 2001 and Pappu, Quester and Cookey 2005).

\section{Relationship between Sports Sponsorship and Brand Awareness}

The concept of brand awareness means a consumer's ability to identify the brand under different conditions, and it consists of brand recognition, brand recalland performance (Keller, 1993). According to Aaker (1999), brand recall is related to the consumer's ability to retrieve information from memory, the brand characteristics and name without any mention of the product category or other competing brands, while brand recognition also termed as aided recall, and relates to consumer's ability to remember past exposure to a brand when provided with brand cues.

Crompton (2004) defines sponsorship awareness as being the first stage in the sequence of sport sponsorship benefits, because to be effective with target customers or audiences, sponsorship must first be known to exist. Therefore, if awareness is not first achieved, the sponsors cannot meet their subsequent objectives. O'Reilly et al. (2007) argue that brand awareness is critical in achieving broader marketing objectives since consumers feel better about the sponsors' brand because of the effect triggered through exposure inside the stadium. In line with this view, previous studies have emphasized on the issue that sponsorship awareness is an important component in consumer's attitudes toward the sponsor's brand and purchase intentions(Schlesinger \&Güngerich, 2011).

\section{Associative network theory}

According to Gwinner and Eaton (1999, p.48), the major objective of sponsors is to stimulate a brand awareness and image transfer from the sponsored event to the sponsored brand. Gwinner (1997, p.149) argues that, events which may be the target of sponsorships convey a certain image through particular attributes and attitudes. According to the Associative Theory,(Gwinner and Eaton,1999,p.149), most companies are motivated to promote their brands at the sport event in order to leverage desirable associations from the event to their brand.

However,Pickton and Broderick (2005), argue that there is the risk that sport sponsorship effectiveness is reduced by the presence of other sponsors at the same event. Basing on the literature discussed, we posit that;

H1: There is a positive relationship between sponsorship and castle lager brand awareness

\section{Relationship between Sports Sponsorship and Brand Loyalty \\ Brand loyalty is defined as a consistent purchase behaviour andfavorable attitude towards a particular brand which can be described as a function of product perceived superiority, synergic effect and social bonding (Oliver, 1997). Caruana (2002) argue that true loyalty only exists when consumers regularly purchases the goods or products and shows a strong attitudinal disposition toward a particular brand and its products.}

\section{Mere exposure theory}

Zajonc (1968), cited in Keillor (2007) noted the mere exposure theory where he suggested that repeated and regular exposure to a stimulus, such as logos, pictures, words or figures, evokes affective responses thereby leading to strong brand loyalty. The research findings by (Keillor, 2007) on the same subject suggest that when mere exposure occurs, the preference and loyalty to the brand is increased. According to Bennett (1999), other studies on the field revealed that in the context of sponsorship mere exposure has significant effects on a brand's name, such as increased recall and brand preference. Therefore, according to mere exposure theory, only by showing or displaying the logo or name of the brand without any other additional information, customer based brand knowledge and brand preference may be positively influenced. According to Olson and Thjomoe (2003, p.243), the mere exposure can be explored through the spectrum of peripheral and central processing in low involvement situations.

The mere exposure theory says that a consumer can process perceived information through the peripheral and central routes. According to Petty, Cacioppo and Schumann (1983, p.135), the central route processing occurs when consumers are highly involved in situation and in-depth considerations needs to be made to process the information. Mere exposure theory goes on to say that if the central route to persuasion has been taken, the consumers mainly focuses on the product-related information provided, for example, attributes, features or product benefits, which could lead to the purchase intention. Keillor (2007) argues that this theory says that, consumers mainly focus on non-product related characteristics, such as humor, color, music, shape and others.

The mere exposure theory says that in the case of peripheral route to customer persuasion and exposure to the brand's name creates priority for that brand in contrast with the others and additional information concerning brand's characteristics is insignificant. However, in contrast Olson and Thjomoe (2003,p.243), argue that when following the central route to customer persuasion, showing only the name or logo of the brand can create weaker brand attitude change, so additional exposure of the brand related information is required in order to improve the brand preference.

Petty et al (1983, p.137), argue that in high involvement situations, the process of sport sponsorship could be perceived as even more effective if brand achieves central information processing. Therefore high involvement brand's information is likely to be proceeded through the central route by the participants or audience. According to Petty et al (1983, p.137) the company could increase its brand loyalty and preference by exposing more brand related information in the frame of the sport sponsorship.

In addition to that, Petty et al (1983,p.138) argue that in low involvement brands, the company should provide not any brand related information but to display or give additional information concerning the sport sponsored event for the purpose of creatingfavorable attitude change and enhance brand loyalty and preference. Therefore, it can be said, that both peripheral and central, cognitive processing of brand might influence the consumer's brand attitude. 


\section{International Journal of Science and Research (IJSR) \\ ISSN (Online): 2319-7064}

Index Copernicus Value (2013): 6.14 | Impact Factor (2015): 6.391

\section{Identification theory}

Tajfel and Turner (1985) developed the social identity theory and they came up with the social classes, such as,university's community or sport participant, organizational member and people, usually identifiesthemselves and others in such categories. According to a study by Keillor (2007), on the field, revealed that social classifications are made because they show a clear way to identify people in the social environment. Therefore when people place themselves in one of the social categories; he or she feel liable for its failure or success(Tajfel and Turner, 1985 cited in Keillor,2007), for instance in this study of Castle Lager Premiership League, people may place themselves in the teams which they support like Caps United, Dynamos, Highlanders, Harare City and others.

This theory explains identification and its effect. Madrigal (2000,p.14), found that people have more favorable intention to purchase when they positively identifies themselves with a particular team and perceives the purchase as a group norm, so in the case of Castle Lager Premiership supporters of participating teams might purchase castle lager brand as a group norm therefore leading to improved brand loyalty.

According toGwinner and Swanson (2003,p.275) in their study in the field they suggested that the more prestigious sport team, the better influence is made on individual's identification with that team and greater influence on key sponsorship outcomes such as sympathetic attitude toward the sponsor, recognition,sponsor patronage, and satisfaction with the sponsor.

\section{Operant Conditioning and Vicarious Learning Theory}

Peter and Olson (2005), defines the operant conditioning as the process of altering the probability of a behaviour being emitted by changing consequences of the behaviour. Therefore, there is a higher chance of repeating the behaviour if the product usage in the past is positively reinforced.

Peter and Olson (2005), argue that positive past experience's reinforcement can be easily shifted to the products, so product usage can be reminded through generating positive feelings towards the product by use of marketing communication elements consequently therefore it is likely that afterwards the consumer would use the product with greater frequency. Clow and Baack, (2002) agree with Peter and Olson (2005) when they say that during event, the sport sponsorship may work as a stimulus, which upliftspositive results of the previous brand use and influences to repeat the usage.

However, the idea of operant conditioning cannot clearly clarify sport sponsorship functioning for a new brand as it only explains sponsorship as a reminder for a wellestablished brand like the Castle Larger Brand.

Vicarious learning is also another idea which explains sport sponsorship process. Peter and Olson, (2005) argue that the observation of other people behaviour cause changing of our own as a result of engaging in vicarious learning. Therefore, according to the vicarious learning idea, if a person is aware of the fact that another person has positive results of using the brand, he or she turns to imitate the behaviour and use the same brand regularly. In the case of Castle Lager sponsorship, sponsored teams can achieve superior performances which are partly attributed to the sponsor brands; therefore consumers can establish the belief that desired behaviour consequence can be achieved by invoking brand usage.

Therefore to sum up theOperant Conditioning and Vicarious Learning Theory of sponsorship, we can say that sports sponsorship triggers various cognitive learning mechanisms. So toimprove recall mere exposure or enhance the preference for a particular brand, Operant Conditioning and Vicarious Learning theories should be employed. Therefore through providing additional information concerning the brand, even the larger brand attitude, change can be obtained if the information is fully processed. Therefore during sports sponsorship both operant conditioning and vicarious learning can take place and induce desired consumer behaviour.

We therefore hypothesise that: H2: There is a positive relationship between sport sponsorship and castle lager brand loyalty.

\section{Relationship between Sports Sponsorship and Perceived Quality.}

Zeithaml (1988) refers quality as excellence or superiority, and extend to perceived quality as the consumer's assessment about an entity's overall excellence or superiority. It is agreeable that perceived product quality should be viewed from the customer's perspective. Parasuraman, Zeithmal and Berry, (1998) argue that perceived quality is the discrepancy between consumer's expectations of a product and their perceptions the actual performance of the product, therefore, perceived quality can be referred to as the product performance (Gronroos, 1993). Parasuraman Zeithamal and Berry (1998), describes the term expectation differently from the satisfaction view, they referred it to expectations in productquality measurement literature, as consumers wants or desires.

Bitner (1992) illustrates the importance of environmental characteristics in service settings through his concept known as the services scape. The services scape comprise of 3 dimensions: spatial and functionality; ambient conditions; and signs, symbols, and artifacts therefore these dimensions affects perceived quality of the sponsoring brand. Wakefield and Blodgett (1996) goes to extend Bitner's(1992) conceptual framework by making further studies on the perceptions of service in the leisure service setting, known as the sports scape. The dimensions of sports scape are:facility aesthetics, layout accessibility,electronic equipment,seating comfort, cleanliness, displays and space allocation.

In addition, Theodorakis and Kambitsis (1998) proposed a perception-performance based measurement, the 


\section{International Journal of Science and Research (IJSR) \\ ISSN (Online): 2319-7064 \\ Index Copernicus Value (2013): 6.14 | Impact Factor (2015): 6.391}

SPORTSERVE formeasuring spectators and perceptions of service quality of professional sports. It is agreed that SPORTSEVE consists of 5 dimensions that are reliability,access, tangibles,responsiveness, and security We therefore make the following proposition: H3: Sports sponsorship has a positive impact on perceived quality of castle lager brand.

\section{Findings And Discussions}

\section{The relationship between Sport Sponsorship and brand awareness}

Linear regression was used to determine the impact of sport sponsorship on Castle Lager brand awareness using SPSS version 16.0to compute the regression analysis as shown in table 1 .

Table 1: Correlation between sport sponsorship and brand awareness

\begin{tabular}{|c|c|c|c|c|}
\hline Model & $\mathrm{R}$ & R Square & $\begin{array}{c}\text { Adjusted R } \\
\text { Square }\end{array}$ & $\begin{array}{c}\text { Std. Error of the } \\
\text { Estimate }\end{array}$ \\
\hline 1 & $.916^{\mathrm{a}}$ & .839 & .837 & .933 \\
\hline \multicolumn{4}{|c|}{ a. Predictors: (Constant), Sport sponsorship } \\
\hline
\end{tabular}

According to the model of summary calculations (Table 1), it is observed that the amount of correlation coefficient of determination between the sports sponsorship and Castle lager brand awareness is $0.839(\mathrm{R}$ square $=0.839)$. Therefore it can be inferred that sport sponsorship for soccer by castle lager accounts for $83.9 \%$ of the variation in castle lager brand awareness. While the remaining $16.1 \%$ variation in brand awareness cannot be explained by castle lager sport sponsorship alone, there could be other factors like advertising and sales promotion, it is observed that Castle lager sponsorship is an effective way of making brand awareness. According to Salkin, 2008, a coefficient value between the range $0.8-1,0$ indicates a very strong positive relationship, therefore the observed $\mathrm{R}$ or standardized Coefficients Beta value of 0.916 depicts a very strong positive relationship between sponsorship and brand awareness of castle lager. The observed significant value of $0.0 \%$ indicates the probability that the obtained $\mathrm{R}$ square value of 0.839 was obtained by chance is less than $5 \%$ hence the effect sport sponsorship has on brand equity is significant. The coefficient B of 0.916 denotes that, the effect sport sponsorship has on castle lager brand awareness is direct. As a result, the authors concluded that the Castle Lager premiership soccer sponsorship has significant impact on castle lager brand awareness. Therefore we accept, H1 which states that there is a positive relationship between sports sponsorship and brand awareness

The results on castle lager brand awareness concur with research by Areska (2012) on his study on the overall brand equity of Red bulls he concluded that eight specific effects of company's sport sponsorship on the Red bull brand are increased brand awareness, brand recall, brand preference, positive attitude towards the brand, brand recognition, positive brand image, brand patronage and satisfaction with the brand. Another study by Benekas (2007), in Greece supports the view that there is a positive relation between sport sponsorship and brand awareness. These results has been supported by the meaning transfer theory proposed by
Keillor (2007), as this theory states that during the sponsored event, sponsor's brand becomes more visible therefore leading to brand awareness and possible for those participating in the process, so strong association between brand awareness and the event will be created. In addition the associative theory proposed by Gwinner and Eaton (2009) supports the view that there is a positive relationship between sports sponsorship and brand awareness as the theory states that companies are motivated to promote their brands at the event in order to leverage associations from the event to their brand.

\section{The impact of sports sponsorship on castle lager brand loyalty}

To determine the impact of sports sponsorship on Castle lager brand loyalty at Delta Beverages, linear regression was applied using SPSS to compute the regression analysis as shown in Table 2 below.

Table 2: Correlation between sports sponsorship and brand

\begin{tabular}{|c|c|c|c|c|}
\hline Model & R & R Square & $\begin{array}{c}\text { Adjusted R } \\
\text { Square }\end{array}$ & $\begin{array}{c}\text { Std. Error of } \\
\text { the Estimate }\end{array}$ \\
\hline 1 & $.817^{\mathrm{a}}$ & .667 & .664 & .776 \\
\hline \multicolumn{4}{|c}{ a. Predictors: (Constant), Sport sponsorship } \\
\hline
\end{tabular}

The observed R Square value (Table 2) shows that the amount of correlation coefficient of determination between sport sponsorship and castle lager brand loyalty is 0.667 inferring that Castle lager sport sponsorship accounts for $67 \%$ of the variation in brand loyalty.Salkin (2008) postulates that an $\mathrm{R}$ square value within the range of 0.6 to 0.79 reflects a strong positive relationship. Based on the assertion above, the observed $\mathrm{R}$ square value of 0.667 depicts a strong positive relationship between sports sponsorship and brand loyalty. The observed significant value of $0.0 \%$ is lessthan $5 \%$ therefore the obtained $\mathrm{R}$ square value was not obtained by chance. The coefficient $B$ of 0.817 denotes that, the effect sport sponsorship has on castle lager brand awareness is direct. Since $67 \%$ of the variation in brand loyalty cannot be explained by sport sponsorship alone, it can be inferred that the impact that sport sponsorship has on brand loyalty is significant. However, it seems that there are other factors which influence brand loyalty of Castle Larger brand like advertising, Sales promotions among other factors. Therefore, we accept $\mathrm{H} 2$ which states that there is a positive relationship between sport sponsorship and brand loyalty.

The findings contradicts with Popes andVoges (2008) as they noted that even if the consumer is loyal and regularly purchased the unsponsored product, sport sponsorship does not positively impact their intention to purchase more of the sponsored product, this difference with the current findings might have been caused by the fact that Popes and Voges (2008), carried a study for FMCG in developed countries, so there is possibility for a difference in less developed countries like Zimbabwe. The results on Castle Lager brand loyalty are supported by the findings of Upshaw in Iran (1995) as they argue that sponsorship cause more loyal customers who are more valuable to the company as they become more loyal and buy the brand more frequently. 


\section{International Journal of Science and Research (IJSR) \\ ISSN (Online): 2319-7064 \\ Index Copernicus Value (2013): 6.14 | Impact Factor (2015): 6.391}

This notion has been supported by the findings by Schlesinger and Gingerich (2011) on their Swiss Ice Hockey Club study as they supported the assumption that highly identified fans are more likely to exhibit positive effect related to the sponsorship than low involved fans. In addition to that, the relationship between sports sponsorship and brand loyalty has been supported by the mere exposure theory by Zanjoc (1968) as this theory suggested that repeated exposure to stimulus like pictures, logos, and figures, evokes effective positive brand image thereby leading to strong brand loyalty. This results has been supported by the Operant Conditioning and Vicarious Learning theory (Peter and Olson,2005) which states that there is great chance of repeating behaviour if usage in the past was positively reinforced.

\section{The impact of sports sponsorship on castle lager perceived quality}

Linear regression was used to determine the impact of sport sponsorship on Castle Lager perceived quality using SPSS in order to compute the regression analysis as follows:

Table 3: Correlation between sports sponsorship and castle lager perceived quality

\begin{tabular}{|c|c|c|c|c|}
\hline Model & $\mathrm{R}$ & $\begin{array}{c}\mathrm{R} \\
\text { Square }\end{array}$ & $\begin{array}{c}\text { Adjusted R } \\
\text { Square }\end{array}$ & $\begin{array}{c}\text { Std. Error of the } \\
\text { Estimate }\end{array}$ \\
\hline 1 & $.757^{\mathrm{a}}$ & .573 & .571 & .885 \\
\hline \multicolumn{5}{|c|}{ a. Predictors: (Constant), Sport sponsorship } \\
\hline
\end{tabular}

Table 3shows the value of $R$ square $(R=0.573)$ which describes the change in castle lager perceived quality variable due to sport sponsorship. The rate of change in perceived quality due to sports sponsorship is $57 \%$. According to Salkin (2008), R square value within the range of 0.45 to 0.59 is a moderate positive relationship. Therefore it can be inferred that $\mathrm{R}$ square of 0.573 shows a moderate positive relationship between castle lager soccer sponsorship and perceived quality of the castle brand. While the remaining $42.7 \%$ variation in perceived quality cannot be explained by castle lager sport sponsorship alone, there could be other factors.

The coefficient B of 0.757 denotes that, the effect sport sponsorship has on perceived quality isdirect. Therefore, we accept H3 which states that the sport sponsorship has an impact on castle lager perceived quality.

In another study by Gwinner and Swanson (2003), concluded that sport sponsorship is highly correlated with other outcome measures of perceived outcome measures of perceived quality. The findings by Robinson and Barlas (2011) agree with the notion that sport sponsorship has an impact on perceived quality because they found that soccer sponsorship by Samsung on Chelsea Football Club provide the basis for the conclusion that Samsung perceived quality in sport sponsorship is derived from sport-related events such as the team and opposing teams.

\section{Summary and Conclusions}

The three dimensions of Yoo and Donthu brand equity model, showed that sport sponsorship by castle lager is effective marketing tool because a positive impact has been realized on brand awareness, brand loyalty and perceived quality. Findings show that castle lager is managing to improve brand awareness, brand loyalty and perceived quality through sponsoring the premier soccer league in Zimbabwe.The results have proven that if sport sponsorship for castle lager is improved, customer satisfaction will be enhanced and it is likely to be the brand of choice for many soccer fans. More research is required on the psychological classifications of consumers and how the various groups respond to sponsorship stimuli.

\section{References}

[1] Aaker, D.A., 1999. Managing Brand Equity: Capitalizing on the Value of a Brand Name. $2^{\text {nd }}$ edition.The Free Press, New York

[2] Areska, D.W., 2012. The corporate (sports) sponsor. International Journal of Advertising,25(11), pp. 307-24

[3] Bennett, R. 1999. "Sports sponsorship, spectator recall and false consensus".European

[4] Journal of MarketingVolume 33 (3/4): 291-313

[5] Bitner, M., 1992, "Servicescapes: The impact of physical surroundings on customer and employees", Journal of Marketing, Volume. 56: 57-71.

[6] Cornwell, T.B. and Roy, D.P., 2003. Brand equity's, influence on responses to event sponsorships. Journal of Product \& Brand Management, Volume 12(6): 377-393.

[7] Clow, K. E. and Baack, D., 2002.Integrated Advertising, Promotion, and Marketing Communications.Upper Saddle River, New Jersey: Prentice Hall

[8] Crompton, J. L. 2004. Conceptualization and alternate operationalization of the measurement of sponsorship effectiveness in sport. Journal of Leisure Studies, Volume 23(3): 267-281.

[9] Caruana, A., (2002). 'Service loyalty. The effects of service quality and the mediating role of customer Satisfaction,' European Journal of Marketing, Volume 36(7/8): 811-828.

[10] Ehrenberg, A.S.C., 1996. "In search of Holy grails: two comments," Journal of Advertising Research, Volume 37: 9-12.

[11] Gronroos, C. 1984, "A service quality model and its market implications." European Journal of Marketing, Volume .18( 4): 36-44

[12] Gwinner, K., 1997. A model of image creation and image transfer in event sponsorship.Journal of International Marketing Review, Volume 14(3): 145-58.

[13] Gwinner, K. and Eaton, J., 1999. Building brand image through event sponsorship: the role of image transfer. Journal of Advertising, Volume. 28: 47-57.

Gwinner, S. and Swanson, S.R., 2003. A Model of Fan Identification: Antecedents and Sponsorship Outcomes. Journal of Services Marketing, Volume. 17: 275-294.

[14] International Events Group. 2006. "IEG Sponsorship report." Retrieved April 14, 2014, from http://imcnorcal.org/Library/2005-07-04_issue.pdf.

[15] Keillor, B.D., 2007. Marketing in the 21st century.Westport: Praeger Publishers

[16] Keller, K.L., $1998 . \quad$ Strategic Brand Management.Prentice Hall, Upper Saddle River, NJ. 


\section{International Journal of Science and Research (IJSR) \\ ISSN (Online): 2319-7064}

Index Copernicus Value (2013): 6.14 | Impact Factor (2015): 6.391

[17] Keller, K. L., 2008. Strategic Brand Management: Building, Measuring, and Managing Brand Equity.Third Edition.

[18] Madrigal, R., 2000.The Influence of Social Alliances with Sports Team on Intentions to Purchase Corporate Sponsors Products.Journal of Advertising, Volume. 29: 14-24.

[19] Oliver, R.L., 1997, A Cognitive Model of the Antecedents and Consequences of Satisfaction Decisions,':Journal of Marketing Research, Volume 4: 460-469.

[20] Olson, E.L. and Thjomoe, H.M. 2003. The effect of peripheral exposure to information on brand performance. European Journal of Marketing, Volume 37: 243-255.

[21] O'Reilly, N., 2005. Methods and Metrics in sponsorship evaluation.Journal of Sponsorship, Volume 2(3): 215230.

[22]Pickton, D. and Broderick, A. 2005.Integrated marketing communications. Harlow, Essex, Pearson Education Limited.

[23] Pope, N., \&Voges, K.E., 2000. Sponsorship and image: a replication and extension. Journal of Marketing Communication, Volume 5(1): 17-28.

[24] Parasuraman, A. Zeithaml, V.A, Berry, L.L., 1998, "SERVQUAL: A multiple-item scale for measuring consumer perceptions of service quality", Journal of Retailing, Volume 64: 12-40.

[25] Pappu,R., Quester, G.P., and Cooksey, W.R., 2005. "Consumer-based brand equity: improving the measurement-empirical effects.”: Journal of Product and Brand Management, Volume 14 (2/3): 143-154

[26] Peter, J.P. and Olson, J.C., 2005. Consumer behaviour and marketing strategy. 7th edition, New York: McGraw-Hill Companies.

[27] Petty, R. E., Cacioppo, J. T. and Schumann, D. 1983 "Central and peripheral routes to advertising effectiveness: The moderating role of involvement" Journal of Consumer Research

[28] Volume 3: 135-146.

[29] Schlesinger, T. \&Güngerich, M. 2011. Analyzing sport sponsorship effectiveness: The influence of fan identification, credibility and product-involvement. International Journal of Sport Management and Marketing, Volume 9(1/2): 54-74.

[30] Tajfel, H. and Turner, J.C., 1985. The Social Identity Theory of Intergroup Behaviour. Journal of Psychology of Intergroup Behaviour,Vol. 2: 7-24.

[31] Theodorakis, $\mathrm{N}$ and Kambitsis, C., 1998, "Relationship between measures of service quality and satisfaction of spectators in professional sports", Journal of Managing service quality, Volume 11 (6): 431-438

[32] Upshaw, L. B. 1995. Building brand identity, New York: John Wiley \& Sons.

[33] Wakefield, K. L. and Blodgett, J. G., 1996, "The importance of servicescapes in leisure service settings", Journal of Services Marketing, Volume 8 (3,): 66-76.

[34] Yoo, B., Donthu, N. and Lee, S. 2000. "An examination of selected marketing mix elements and brand equity", Journal of the Academy of Marketing Science, Volume28(2): 195-211

[35] Yoo, B. and Donthu, N. 2001, "Developing and validating a multidimensional consumer based [36]brand equity scale". Journal of Business Research, Volume 52: 1-14.

[37] Yoo, B and Donthu, N. 2002, "Testing Cross-Cultural Invariance of Brand Equity Creation Process," Journal of Product \& Brand Management, Volume 11 (6), 380398 Available at: http://people.hofstra.edu/Boonghee_Yoo/papers/2002_J PBM_BE\%20Invariance.pdf

Zajonc, R.B., 1968. Attitudinal Effects of Mere Exposure.Journal of Personality and Social Psychology, Monograph Supplement, Volume 1: 1-27.

[38]Zeithaml, V., Berry, L. \& Parasuraman, A,. 1996. 'The Behavioral Consequences of Service Quality': Journal of Marketing, Volume 60(2): 31-46.

[39]Zeithmal, V. A., Parasuraman, A and Malhotra, A, 2005, A conceptual Framework for Understanding Eservice quality: Implications for future Research and Managerial Practice, working paper, Report No 115, Marketing Science Institute. 